\title{
Review on Impacts of Rural Land Registration and Certification on Small Holder Farmers in Ethiopia
}

\author{
2018 \\ MULU KABA $^{1}$ HISA MUSA ${ }^{2}$ \\ 1. Jimma University \\ 2. Asossa University
}

\begin{abstract}
Land is becoming increasingly scarce for Ethiopia particularly for rural households and a source livelihood and as the same time cause of conflict and dispute between and within groups in rural household. The objective of the seminar is to review the impacts of land registration and certification on rural households of Ethiopia. In Ethiopia for the past ten years over 9.1householdrs were received land certifications. Even though such amount of landholders of received land certifications there is a gap of perception between region to region as well as farmer to farmers. The review also assesses different governments' rules, policies and land legislation from Emperor to EPDRF. In Emperor Regimes land was freehold tenure, provide individual titles of land and facilitate land sales. In Derg there was abolished the tenant-landlord relations and land was to tiller but land could not sold and exchanged. According to EPDRF policy land is both private and public owner ship, so it could be registered and certified and not to be sold exchanged. But still there is different disagreement on land titling and tenure security. Some scholars said that land registration and titling can create conflicts over land rights. While other, said under productivity and low investment is due to land was under governments. But it will be better if contending parties listen what the people say and take into account the social, cultural and historical contexts of the society before designing and revising land policies and strategies. At the end it summarizes with more outcomes will be achieved through stockholders participation.
\end{abstract}

Keywords: land, land registration, certification, impact, policy

DOI: $10.7176 / \mathrm{JESD} / 12-15-02$

Publication date:August $31^{\text {st }} 2021$

\section{INTRODUCTION}

\subsection{Background}

Land is a fundamental asset for economic development, food security and poverty reduction in sub-Saharan Africa and has a crucial importance to the economies and societies of the region (Cotula, et al., 2004). Payne, B.K., (2006)defines land tenure as the mode by which land is held or owned, or the set of relationships among people concerning land or its product. The importance of land to a country's development is emphasized by the fact that most of the population derives their livelihood from land through activities such as farming, livestock production, industry, construction and other activities (Lugoe, 2008). Land tenure systems are defined by societies to determine access to specific uses of a certain piece of land and the distribution of the benefits that accrue from these (Wubneh, M., 2018). It comprises: legal framework, tenure administrative framework and organizational framework and infrastructure (Lamba 2005). Tenure security in general terms could be seen as an individual's perception of his or her right to a piece of land on a continual basis, free from interference from outside sources as well as the ability to reap the benefits of investments in land (Kuusaana et al.,2013).Most land in sub-Saharan Africa has no registration of who owns it or has rights to use it. Successive national governments in Ethiopia have implemented differing approaches to the distribution of rural land.

Ethiopia's political history and land related policies are characterized by the fact that during the last 50 years three distinct political systems governed the country. Each of these political regimes is different in that they were driven by different ideologies: 'feudalism', 'socialism' and 'market oriented' respectively (McKe.et al., 2016). Despite these 'structural' differences, the land related policies that were implemented did not provide land tenure security. Various new initiatives are underway to address this, in the belief that land registration and titling can promote investment, reduce poverty and encourage better natural-resource management (Delville, 2010). The first land registration and cadastral survey in Ethiopia was initiated in Addis Ababa in 1909 (Holden, Tefera, 2008). Ministry of Land Reform and Administration that measured and registered rural land in collaboration with the mapping agency until 1974 aiming to create a system of freehold tenure, provide individual titles of land and to facilitate land sales (Crummey, , 2006). However, land remains the point of controversy and political grievances during the past regimes and tenure insecurity was high in the country.

The 1975 land reform of the Derg has been considered by many as a radical measure that has abolished the tenant-landlord relations in Ethiopia (Hosaena et al., 2013).The rural land reform proclamation ("Proclamation to Provide for the Public Ownership of Rural Lands", No. 31/1975) stated that feudal lords had exploited the 
peasantry. It aimed at fundamentally altering the agrarian relations and liberating the peasantry increasing agricultural production; creating employment; distributing land and increase rural income and laying down the basis for the expansion of industry (Yigremew Adal, 2002). The provisions of the proclamation include: public ownership of all rural lands; distribution of land to the tiller in provinces with privately owned rural land (art 4); prohibitions on transfer of use rights by sale, exchange, succession, mortgage or lease, except upon death and then only to the wife, husband, or minor children and, in the case of communal lands, possessory rights over the land the peasants till at the time of the reform (Art. 19).

Immediately after the downfall of the Derg, nobody was certain what course the new government would take regarding land tenure. The Transitional Government itself had declared that the issue of private versus public ownership would be settled in the process of developing the new federal constitution (Yigremew Adal, 2002). When the new federal constitution came out, the issue was settled in favor of public ownership of land. Then, like the Derg, the present government maintained the state ownership of land. "Ethiopian peasants have right to obtain land without payment and have the protection against eviction from their possession" (FDRE 1995). The government is the ultimate owner of land using the power given by the constitution (Assefa Belay, 2010). According to Zerfu Hailu (2016), the 1995 constitution has covered the way for developments of land administration legal frameworks at federal and regional levels. At federal level, for rural land administration, proclamation $89 / 1997$ was the first proclamation that is replaced by proclamation $456 / 2005$. Several regional governments have formulate their land policies and land laws, among them Tigray Region proclamation 136/2007 (first issued 1997, amended 2002 and 2007), Amhara Region 133/2006 (first enacted 2000, amended in 2006), Oromia Region 130/2007 (first issued 2002, amended in 2007), and SNNP Region 110/2007 (first enacted 2003, amended in 2007), Afar Region 49/2009, Benishangul Gumuz 85/2010, Gambela Region $185 / 2011$, and Ethiopia Somali Regional State 128/2013.

The country has implemented one of the largest, fastest and least expensive land registration and certification reforms in Africa (Deininger et al., 2008). While there is some variation in how land registration and certification has been implemented across, and even within, regions in Ethiopia, the broad scale first stage land registration and certification involved the registration and demarcation of land plots using simple local technologies that required little training. The main sources for determining plot boundaries were field markings, in conjunction with the memories of the neighbors whose farm plots border those owned by the households in question. Measuring tapes and ropes were used to measure the farm plots. While the initial cost of this registration was extremely low, its impact in improving tenure security has been significant, as evidenced by increased investment, land productivity and land rental market activity (Deininger et al., 2008, 2011; Holden et al., 2009, 2011a; Bezabih et al., 2012).

The primary goal of the rural land certification program is to strengthen farmers land entitlement, land rights in the Ethiopia, points to limitations on the extent to which certificates alone can fully achieve the program's intended objectives (Holden et al. 2009). Land certificates are expected to significantly affect these underlying barriers that hinder Ethiopian rural farmers right to land that are deeply rooted in Ethiopia traditional rural society. Therefore, the determination of the degree to which the certification programs affect tenure security needs to be assessed in light of the complex interaction between key economic and societal factors and the land certificates provided to rural households of Ethiopia (Ayalew et al. 2008).

\section{2 statements of the problem}

Land tenure security is believed to be important in improving investment in land, land management and sustainable use of natural resources. Land titling increases security of tenure and the increased security leads to reliability and collateralization effects. Brasselle et al. (2002) showed that the certification of landowner will obtain long term benefits from the land. The ability to realize immediate fungibles from the land not only create incentives for the landowner to invest in the land in optimization of productivity and developmental activity but also the impacts of land registration lead to the establishment of information systems that can be used to support transactions in land or land management activities. Both of this impact must take place within an environment of system maintenance to continue to function.

In Ethiopia land registration and certification was started before ten years. Although land registration and certification was impact on investing their land for many landholders through tree planting, terracing, fencing and manure etc, It is also suggested that the indicators of poor performance of the agricultural sector under the existing tenure arrangement are; insecurity of holding rights, reduction of holding size and subsistence farming practices(Nega, Adenew et al. 2003). As a consequence the issues of land become the point of argument among different actors who have interest in land. For instance, Nega, Adnew et al. (2003) found that landholders were not willing to made land improvement activities because of the fear of future redistribution. The review was done to assess what impact was brought on individual farm land of rural householders and review what ideologies and polices in relation with rural land in Ethiopia. 


\subsection{Objectives}

\subsubsection{General objectives}

The general objective of a seminar is to review the impacts of rural land registration and certification on small holder farmers in Ethiopia.

1.3.2 Specific objectives

The specific objectives are to:

1) To review Land registration and certification impacts on rural households in Ethiopia

2) To review different polices and ideologies on land ownership in Ethiopia.

\section{THE IMPACTES OF RURAL LAND REGISRATION AND CERTIFICATION ON SMALL HOLDER FARMERS IN ETHIOPIA}

\subsection{Theoretical review}

\subsubsection{Definitions and concepts of land policy issues}

Land is defined as the "surface of the earth, the material beneath the air above, and all things fixed to the soil, so it is more than just 'land' alone: it includes buildings, etc" (van der Molen, 2002). Land can be also described in a wider sense from legal point of view which refers to any portion of the earth surface where land rights are exercised and such rights are not just ownership to the surface, and it includes every object attached to it above or below the surface (Tuladhar, 2004). Since land has a multi dimensional impact on every societies, effective and efficient management is a vital prerequisite for economic development and environmental sustainability. Therefore, land policy of a country whether developed or developing; have a crucial role to make sure sustainable development and the way governments deal with land is an important issue of government development policy. Torhonen (2004) advocates land policy as "land policy is taken as a governmental instrument that states the strategy and objectives for the social, economic and environmental use of the land and natural resources of a country."

\subsubsection{Definition and concept of Land Administration}

Universally, land administration is understood as the process of determining, recording and disseminating information about ownership, value and use of land, when implementing land management policies. It is also considered to include land registration, cadastral surveying and mapping, fiscal, legal and multi-purpose cadastres and land information systems (Steudler, Rajabifard et al., 2004). "Land administration is not a purpose in itself; moreover, it aims at serving the society with land policy being implemented through land management activities. Such a land policy makes unambiguous the governments' decisions on the whole complex of socioeconomic and legal prescriptions as to how the land and the benefits from the land are to be allocated. Therefore, land administration is to be seen as a tool for facilitating these land management instruments (van der Molen, 2002). "Land management," on the other hand, addresses all issues related to the sound and sustainable use of land. It is the process by which the resources of land are put to good use (USAID, 2004). It covers all activities concerned with the management of land as a resource both from an environmental and an economic perspective.

\subsubsection{Definition and concept of Land Tenure}

Obviously, there could be different conceptual definitions used for the term land tenure given by different scholars. However, it seems imperative to have a working definition of the concept land tenure. FAO (2002) defines land tenure as "the relationship, whether legally or customarily defined, among people, as individuals or groups, with respect to land." Tenure rights are a set of rules and norms that determine who can use what resource, under what conditions, and for how long (FAO, 2009). Moreover, Land tenure is an institution, i.e., rules invented by societies to regulate behavior. Rules of tenure define how property rights to land are to be allocated within societies. They define how access is granted to rights to use, control, and transfer land, as well as associated responsibilities and restrictions. Bugri (2008) defines land tenure security as "the ability to continually cultivate land without interference." This probably presents an acceptable definition for both males and females.

Land access refers to the availability of land and ownership security, desirable physical and economic attributes, reliable credit and property information and the level of transparency and fairness of transactions (Ahene, 2009). Generally, rights of access to land can take the form of use rights, control rights and transfer rights (Ostrom and Hess, 2007). Similarly, land tenure may be seen as an institutional structure that determines how individuals and groups secure access to the productive capabilities of the land or other uses over the land (Bell, 2006). ECA (2004) land tenure is a social construct that defines the relationships between individuals and groups of individuals by which rights and obligations are defined with respect to control and use of land.

A strong argument could be made for advocating tenure security with the expectation that if farmers own the rights to their land, they are more likely to make long term investments. This goes not only to farmers' desire to invest but also to their ability to make those investments (Brasselle et al., 2002). Land that is secure and liquid incentivizes farmers to make efficient use of their resources through flexible allocation of resources (Deininger \& Jin, 2006). In addition to economic benefits, for which many economists have made a case for (De Soto 2000), 
there exist considerable social spillovers (Conning et al., 2010).

\subsubsection{Federal and regional land proclamations and implementation rules (regulations)}

The federal government states that peasant farmers, pastoralists and semi-pastoralists can transfer their rural land-use rights through donation (FDRE, Proc. No. 456/2005, Art.5.2) or inheritance (FDRE, Proc. No. $456 / 2005$, Art. 8.5) to members of their family and can also rent/lease part of their holdings to other farmers or investors for a specified period (FDRE, Proc. No. 456/2005, Art.8.1).The same is true of rural land proclamations by different regional states. Rural land proclamations by ANRS state that holders of rural land may transfer their land use rights through inheritance to family members who are or wish to be engaged in agriculture (ANRS, Proc. No. 133/2006, and Art. 16.1). In the SNNPRS, the proclamation says that transfer through inheritance only applies to rights holders in the family (SNNPRS, Proc. No. 110/2007, and Art. 8.5). The same is true in ONRS (ONRS, Proc. No. 130/2007, and Art.9.1). The proclamations in ONRS and SNNPRS make being a rural resident a condition for inheriting rural land. Rural land that is transferred through inheritance must be in compliance with the minimum size of holding (FDRE, Proc. No. 456/2005, and Art.11.2). The vast majority of rural holdings are small (less than 2 hectares) and fragmented (average holdings of 2.3 plots), many farms are less than one hectare and a not-insignificant number of households are landless (Griffin et al., 2001; Abegaz 2004;Gebreselassie,Rahmato\&Assefa2006).

\section{Table 1. Tenure typology for the rural land sector}

\begin{tabular}{|c|c|c|c|}
\hline \multirow{2}{*}{$\begin{array}{l}\text { Type of } \\
\text { tenure }\end{array}$} & \multicolumn{3}{|c|}{ Legal recognition, registration, transferability and characteristics State land } \\
\hline & Legal recognition & Registration/recording & Transferability \\
\hline State land & $\begin{array}{l}\text { Recognized as state } \\
\text { holding by the federal } \\
\text { Rural } \\
\text { Administration and Land } \\
\text { Use Proclamation (No. } \\
456 / 2005 \text { ) and regional } \\
\text { land laws. }\end{array}$ & $\begin{array}{l}\text { The surveyed land is ready for the } \\
\text { transfer to investors (domestic and } \\
\text { foreign) through lease contracts. } \\
\text { Sometimes is termed as land grabbing } \\
\text { (Rahmato, 2011). } \\
\text { The maximum duration for the } \\
\text { leasehold is different in different } \\
\text { regions and renewed after the expiry } \\
\text { period. }\end{array}$ & $\begin{array}{l}\text { State land is transferred by } \\
\text { lease agreement with the } \\
\text { regional states. } \\
\text { The lease can also be } \\
\text { inherited for the term and } \\
\text { legal heirs are willing to } \\
\text { continue to abide with the } \\
\text { previous lease contract. }\end{array}$ \\
\hline $\begin{array}{l}\text { Private } \\
\text { holding }\end{array}$ & $\begin{array}{l}\text { The land holding right is } \\
\text { given by constitutional } \\
\text { provision and further } \\
\text { clarified by federal } \\
\text { framework land law } \\
\begin{array}{l}\text { Proclamation } \\
456 / 2005\end{array}\end{array}$ & $\begin{array}{l}\text { Four major regional states are issuing } \\
\text { primary books of holdings following } \\
\text { participatory adjudication process. It is } \\
\text { estimated to } 60 \text { to } 98 \% \text { of the land } \\
\text { holders in the four major regional } \\
\text { states }\end{array}$ & $\begin{array}{l}\text { Private individual holdings } \\
\text { cannot be sold and can be } \\
\text { transferred only through } \\
\text { inheritance to family } \\
\text { members. }\end{array}$ \\
\hline $\begin{array}{l}\text { Communal } \\
\text { holding }\end{array}$ & $\begin{array}{l}\text { Access rights to } \\
\text { communal holding over } \\
\text { rural land are recognized } \\
\text { by the constitution and } \\
\text { proclamations (Proc. No. } \\
456 / 2005 \text { ). }\end{array}$ & $\begin{array}{l}\text { Registration of communal holdings in } \\
\text { four major regions is similar to } \\
\text { individual holdings except that the } \\
\text { holders of communal holding are } \\
\text { group of people. In pastoralist areas } \\
\text { the group, clan is the owner of the area } \\
\text { of land that they are not permanently } \\
\text { settled on the area. }\end{array}$ & $\begin{array}{l}\text { Proclamation } 133 / 2006 \\
\text { defines the common holding } \\
\text { as rural land under the } \\
\text { ownership of the local } \\
\text { people in common for } \\
\text { different social services. } \\
\text { Communal rural land } \\
\text { holdings can be changed to } \\
\text { private holdings as may be } \\
\text { necessary" (Proc. No. } \\
456 / 2005 \text {, Art. 5-3). }\end{array}$ \\
\hline $\begin{array}{l}\text { Leasehold } \\
\text { /rental }\end{array}$ & $\begin{array}{l}\text { Private investors can get } \\
\text { time bound use rights on } \\
\text { payment over rural land } \\
\text { to engage in commercial } \\
\text { activities with the state } \\
\text { or private land holder } \\
\text { (Proc. No. 456/2005, } \\
\text { Art. 5/4 and art.8). }\end{array}$ & $\begin{array}{l}\text { Any rural land that is held through } \\
\text { lease or rental shall be registered by } \\
\text { the competent authority ((Proc. No. } \\
456 / 2005 \text {, Art. 6/). }\end{array}$ & $\begin{array}{l}\text { Investors who hold rural land } \\
\text { through lease or rent have } \\
\text { the right to transfer and use } \\
\text { as collateral their holding } \\
\text { right }\end{array}$ \\
\hline
\end{tabular}

Taken from World Bank, (2016)

\subsubsection{Land registration and certification process in Ethiopia}

Land administration system comprised of textual records that define rights and/or information, and spatial records that define the application of rights. The application of the above definition is on rural land only and basic components like security of holding rights, land use planning and dispute resolution mechanisms are 
included. In addition, as part of the land administration process, the task of collecting, organizing and disseminating land information to users is incorporated (Burns, Grant et al. 2006). The Ethiopian certification program has contributed to the largest delivery of non-freehold land rights per time unit in Sub-Saharan Africa. The federal Land Administration and Land Use Proclamation No. 456/2005 provide that farmers have a perpetual use right on their agricultural holdings, and this right will be strengthened by issuing certificates and keeping registers (Klaus D.et al., 2006).

The program has been implemented in the four most populous regions of the country: Tigray, Amhara, Oromiya and the Southern Nations and Nationalities (SNNR). The Tigray region started the land registration and certification process in 1998 to 99, followed by the Amhara region in 2003, with Oromiya and SNNR's certification commencing in 2004 (Holden et al., 2009). The main actor in data collection for the registration and issuance of the certificates is a committee at the lowest level of local government (kebele or sub kebele). The members of these so called Land Administration Committees get training to undertake this endeavor, but do not get paid for their time. The LACs are primarily involved in land registration and certification. The certification and registration process is carried out in a participatory manner where the work by LACs is at large uncompensated (Holden and Teferra, 2008).

The permanent certificate will be offered when a map of individual holdings is prepared, using the land information and data, and given to the holders (Adnew and Abdi, 2011). According to World Bank (2016), in Ethiopia, specifically in first level registration and certification as presented in table 2 out of 11.5 million rural households' 9.4 million households have received first level holding certificates.

\begin{tabular}{|c|c|c|c|}
\hline \multirow[t]{2}{*}{ Regions } & \multirow[t]{2}{*}{$\begin{array}{l}\text { Total rural } \\
\text { households }\end{array}$} & \multicolumn{2}{|c|}{$\begin{array}{l}\text { Received first level land holding certificates (total } \\
\text { achieved ,including male and female households) } \\
(2006-2016)\end{array}$} \\
\hline & & Total achieved & $\%$ \\
\hline Amhara & $3,500,000$ & $3,325,000$ & 95 \\
\hline Oromia & $4,014,500$ & $3,091,165$ & 77 \\
\hline SNNP & $2,979,851$ & $2,289,571$ & 76.8 \\
\hline Tigray & 695,000 & 688,050 & 99 \\
\hline Harari & 13,543 & 1,125 & 8.3 \\
\hline Dire Dawa & 21,000 & 500 & 0.023 \\
\hline Gambela & 53,000 & 2,000 & 3.8 \\
\hline Somali & 101,554 & - & \\
\hline Afar & 27,765 & - & \\
\hline Benshangul Gumuz & 125,175 & - & \\
\hline Total & $11,531,388$ & $9,397,411$ & 81.5 \\
\hline
\end{tabular}

Table 2 households get $1^{\text {st }}$ level certificate taken from, Zerfu Hailu; (2016)

\subsection{Empirical Evidences}

\subsubsection{Impacts of land registration and certification on farm house holds}

There are numerous case studies conducted in other areas that show the role of land registration and title certification in ensuring tenure security. Berhanu et al (2003) argued that land titling and legal enforcement of title are considered fundamental for tenure security. They had shown that more secure land tenure and land rights enhance farmers to make investment on land. Sikor (2005) in his study in the northwest Vietnam assured that land registration and title certification is counterproductive to rural peoples of the country by avoiding the economic and political uncertainties and providing tenure security to the region. A study by Kabubo-Mariana and Linderhof (2009) in two provinces of Kenya (Naro and Kajado) show that land management practices strengthened as a result of land tenure security which was brought due to land registration and title certification in the region as the cost of other incentives. Deininger and Jin (2006), found that land transfer rights and tenure security are associated with higher investments in a study from 2001 covering four regions of Ethiopia. Holden et al. (2009) found significant positive effects of low-cost land certification on investment in trees and maintenance of soil conservation structures in Tigray Region, using a household plot panel with baseline data from just before land certification and the last survey round seven to eight years after the land registration and certification took place. Holden and Ghebru (2013), found that the certification had resulted in increased food production and food access for poor female-headed households who share cropped out their land. A study by Amare Belete T. (2013), showed that, in Oromia, 90\% of the households are more likely to plant trees on any plot and $86 \%$ of the households believe that legalizing land ownership through certification will encourage them to plant trees on their land. Similarly in Wollita, $79 \%$ of households are likely to plant trees on any plot and $64 \%$ believe that certification would have a positive impact on tree planting.

A study also conducted by Sabita (2010), explained regarding fear of redistribution, in the Ethiopian rift 
valley system Meskan in SNNP and Adami tullu Jido kombolcha (AJK) in Oromiya show that 90\% of respondents replied that land certification ensured tenure security of farmers on their lands by avoiding fear of land redistribution in the near future. Another study by Holden et al (2008) in Tigray show that about $97 \%$ of Hana-Mariam kebele and 95\% of Kuria Kebele households perceived that there will not be redistribution of land in the near future. On the other hand only $2.5 \%$ of Hana Mariam and $5 \%$ of Kuria Kebele households perceived that there will be redistribution of land in the near future. The finding of Assefa (2010), in Amhara region (Fagetalekoma District in Awi zone) shows, 85\% of the respondents are confident that future land redistribution will not take place and $15 \%$ of the studied households have a fear of future land redistribution.

Another study done by Stein T et al.,(2016), in Ethiopia shows proportion of farm households who were engaged in conservation their own plots is slightly higher, at 94.3 percent, for those with a land use certificate than for those without the certificate, only 83.9 percent. Similarly, the percentage of households who had considered improving or maintaining an existing conservation structure is also significantly higher for those with a certificate, 40.7 percent, compared with only 28.6 percent for households without a land certificate (Stein T. Holden 2015). A study by Holden, Deininger, and Ghebru (2009), in new technology adoption, the summary result also depicts a higher likelihood of application of chemical as well as organic fertilizer (53 percent and 29 percent, respectively) on plots with a land certificate than on plots without a certificate (only 46 percent and 23 percent, respectively). Other study done in Amhara region showed that certification encourages landholders to invest in soil and water conservation works $(95.16 \%)$, planting trees $(92.29 \%)$, and $(92.83)$ have the desire to undertake land related investment after certification (Ayalew et al. 2008).

Another case study in Amahra survey result confirmed that $64 \%$ of the respondents reported they face land related dispute and $27 \%$ responded they never faced dispute over land before certification. On the other hand, majority of respondents (66\%) confirmed that they did not faced land related dispute after certification and $33 \%$ reported they are affected by land related disputes after certification (Assefa Belay, 2010). A study made by Sanga (2009) in Nigeria show that $60 \%$ of respondents prefer their land to register because it makes them confident that even the land is safeguarded in their absence. According to the study conducted by Palm (2010) in Amhara state tenure security is highly appreciated by farmers, and hence resulted in increasing of land investment activities. Deininger et al, (2005) generally conclude that land certification and registration can reduction of conflict women's empowerment, increased individual or communal investment, increased and security against expropriation.

Contrary to above some scholars argue that land registration and certification have to same extent has negative consequences. The certificate of land ownership can allay fears that rental land can be taken away, either by the government through redistribution or by a tenant who does not vacate it at the end of the lease period (Deininger ,G. Feder, 2009). As it is repeatedly explained, fear of future redistribution of land is significantly affected by landlessness, which also tends to affect the use of several land improving technologies negatively (Benin and Peder, 2001). Berhanu et al (2003), founded only 27\% of their respondents are certain that there will not be redistribution of land in the near future whereas $73 \%$ of their respondents were confused regarding the possibility of future land redistribution and indicator of insecurity is farmers' expectations of future land distributions in their study area.

Despite the fact that most regional governments have publicly dissociated themselves from possible future land redistribution, only a minority of farmers ( 27 percent) are convinced that this will not occur in the future. By contrast, a significant majority ( 73 percent) feel either uncertain about the future or are certain that there will be redistribution. Of those farmers who think that there will be redistribution, a large majority (70 percent) feel that this could take place before 2005. On average, 10 percent of the sample has experienced land redistribution since 1990 (Toulmin, C. \& Quan, J. 2000). Some scholars, however, argue that even though the land registration program was a positive step, the effort it was not sufficient to address the basic issues about lack of clarity regarding security and property ownership. While the regional governments are assuring there will be no land redistribution, the federal land policy is still remained stating that redistribution is the only way by which the peasants may lose their land. Therefore, user right documentation failed to assure security of tenure in the full sense of the world (Atalkilte, 2003).

Although new initiations of use right documentation, tenure insecurity still remained the overriding problems of land system in country. A study made by Mitiku et al (2005), in northern Ethiopia showed that the new land tenure rules are unclear and the peasants fear that they may be vulnerable to title changes. Inefficient and corrupt bureaucracies and high costs of conventional land titling have also caused rationing out of poor and vulnerable groups and have favored the wealthy Land registration and titling can create rather than reduce uncertainty and conflicts over land rights (Benjaminsen et al., 2009). Other studies have revealed no significant investment or credit access effects of land titling (Jacoby and Minten, 2007). Contradictions between customary land rights and new statutory land rights can create uncertainties and conflicts that enhance tenure insecurity for some groups and individuals. For land registration and the issuance of title documents to be effective, cadastral surveys and modern system of record keeping are essential without which 
the program could lead to conflict and uncertainty. Therefore, new problems and new conflicts will arise in the future if modern technology is not employed (Desalegn, 2000).

\subsubsection{Strength and weakness of land registration and certification in Ethiopia}

The Ethiopian government has begun implementation of 'land certification program' hoping that it improves tenure security of peasants. Accordingly, the four regional states of Oromia, Amhara, Tigray and the Southern region are conducting land registration with different approaches and methodologies (ELTAP, 2006). Amhara, Oromia and SNNPR are the process has been set up relatively quickly, especially in Amhara with great enthusiasm on the top, which also seems to infect others involved in Amhara balance has been found by local participation in the process, combined with expert support from woreda officials. The results of the certification process in Tigray are well accepted. This is due to the high acceptance of the last land redistribution in Tigray as being fair, as well as general faith in the local authorities (Michael et al., 2005). In Oromia the strong reliance on community work, makes the process very participatory, combined with well set up and supported training program including materials and percentage of holders reached is already large enough to make a real impact on the way certain land administration activities can be executed in all regions.

Lack of adequate demarcation, registration and record keeping has led to overlapping land claims stemming from inheritance that is beginning to result in conflict. Weak government and customary institutions, population growth, frequent drought, resource degradation, and encroachment or expropriation of rangelands are some of the causes of inter-pastoral conflicts and between pastoralists, the government, and farmers (Michael et al., 2005, Hundie, B. 2006).A weakness also includes workload for some local people who do not get compensated is rather heavy, there is a risk that they will 'compensate' themselves or 'suspend' the work for extensive times. In Oromia there is not enough support from the woreda during data collection, and lack of capacity to follow up the collected data with the actual issuing of certificates (Daniel Ayalew et al., 2006) procedure was not well spelt out, and the level of community participation seems to rely on local implementation (the presentation meeting was clearly not standard) and certificates were issued, even when certain households or plots were not registered; discussion can later emerge on already certified land.

There is not enough support from the woreda during data collection, and lack of capacity to follow up the collected data with the actual issuing of certificates and the book is too small and condensed with only one line per household, not leaving any room for updating (Zevenbergen et al., 2005). In Oromia no copy of the book of register is kept at the kebele, and position of those who are away at the wrong times is not well secured Lack of awareness in the communities was found to be large in SNNPR (73\%), Oromia (71\%) and even Amhara (54\%) based on the EEA/EEPRI's 2004 survey (Orgut, 2005). Another shortcoming of regional legislation is the lack of mechanisms to secure rights of pastoralists to customary grazing lands in the lowland areas of the country where pastoralists must travel across broad landscapes in search of food and water for their animals (Ambaye 2012)

\section{THE DIFFERENT POLICES AND IDEOLOGIES ON LAND OWNERSHIP IN ETHIOPIA}

\subsection{The theories and current debate on land tenure in Ethiopia}

Rural land policy has remained one of the sources of disagreement and focus of debate among politicians, academicians and other concerned parties in Ethiopia. During the transition period of the current regime, when the government had not yet defined its policy on rural land, much concern was shown by different sections of the society as well as by international agencies and the issue had been the focus of debate. Later on, the ruling party made it clear that the policy on land was to continue more or less on the same lines to that of the Derg's policies (Yigremew Adal, 2002).

Binayew Tamrat G. (2015) was explaining, land ownership Political scientists, social anthropologists, economists, government officials and to some extent journalists are involving as major actors in the ongoing debate on issue of landownership in Ethiopia to post Derg Period. He further elucidated that the beginning the debate was between political parties. In the FDRE constitution, article 40 sub article 3, stated that 'the right of ownership of rural and of all natural resources is exclusively vested in the state and in the peoples of Ethiopia'. The EPRDF leadership officially declared that the issue has been constitutionally resolved. Land is the common property of the "Nations, Nationalities and Peoples of Ethiopia", and it cannot be sold, exchanged and mortgaged or to other means of transfer (Allan Hobben, 2001; Atakilte, 2003).

On the one hand, it gives the government the right to expropriate the land for public purposes and to give to private investors the right of use on the basis of payment arrangements (Atakilte, 2003). The Government's underlying assumptions and justifications for its policy of public land ownership include the following socioeconomic equity issues. Every rural individual has the right to a plot of land sufficient for his or her livelihood and should claim the right in his or her kebele or locality (economic reason). If land is privately owned, it is impossible to full-fill such a right but rather can create peasant dispossessions through distress sales or evictions. This might concentrate land in the hands of the few (particularly the urban upper middle class) with concomitant effects of widespread poverty and landlessness. The government has been employing various instruments to tackle the problem of landlessness. These include periodic redistribution; expropriation of land from those who 
fail to full certain obligations and transfer of said land to landless individuals; and, more recently, privatization of the hill sides and Promoting social equity among the rural dwellers.

Land ownership by the state is also as a means to narrow the gap between the rich and the rural poor, thereby mitigating the disparity in wealth and property that is the cause of antagonism and class conflict (Desalegn Rahmato 2008). Moreover, the ruling party and its supporters defended that peasants' right for land are guaranteed by granting ownership certificates. To strengthen their sense of ownership to their land, peasants have been registered and received land holding certificate. Usufruct rights prohibit land holders the right to sell or mortgage it (Temesgen Gebeyehu, 2013). As a response to their strong desire to make land a private property and saleable as a commodity, the former EFDRE prime Minister defended that "land privatization in Ethiopia would take place only over the EPRDF's 'dead body' Samuel (2006:78)". Moreover, EPRDF and top government officials repeatedly notified that debating on constitutionally resolved issue is a 'sterile' argument (Allan Hoben, 2002). Proponents of this policy said if land was sold, it could lead to unproductive accumulation of land or translate immediately to the creation of a large landless class that could destabilize the social system.

There are some scholars who stood in support of state ownership position. Fantu Cheru and Marquardt (2006), for instance, proposed that land to be under state for equity reasons. Like the EPDRF led government, Fantu strongly defended land privatization. In justifying his position, Fantu expounded that reinstating a western style property right and land selling would led the country to its pre- 1974 situation during which large number of peasants were made to be landless and forced to join the urban destitute ( Fantu C ,1994). Moreover, he suggested state ownership for equity reasons. For him land has to be under state ownership so that it could be distributed to the rural people equitably and land tenure security, and could be maintained through legislation. Most of the opposition parties have been arguing land to be owned privately. Obviously, the government used land redistribution not for the sake of achieving equity as intended but rather as a political weapon to assault what it called "remnant bureaucrats of Derg" (Temesgen Gebeyehu, 2013). Allan Hoben (2002), in many of his articles which he wrote in support of land privatization, and concluded that the only way to provide tenure security for peasants is, land privatization. Based on empirical reasons, the same scholar made the government's fear of consequential dangers of allowing land for sale groundless.

On the other hand, the provisions grant the peasants the right to: Obtain land without permanence; The protection against eviction from their possessions; Enjoy full rights to improvements one brings about on the land by labor and/ or capital: including the right to alienate, to bequeath, to remove ones property when one's usage rights expire, to transfer his/her title or claim compensation for it (Dasalegn Rahmato 2008). Hence considering itself as defender of the rural society and the peasants in particularly, the EPDRF strongly opposed the idea of private land ownership and land sale. The advocates of private ownership for their part strongly objected the governments' justification. Rejecting the state's rhetoric as defender of peasants, they argued that even though the government kept the land under its control to address the problem associated with peasants' eviction "landlessness refused to disappear". This is because the state itself has involved in the process of making peasants landless.

They asserted that the government itself has been snatching and evicting peasants living in the semi urban areas (Ibid; EEA, 2002). In their struggle for private ownership the issue of land sale is invariably taken by economists and western oriented advisors as a central agenda. They criticized the state's effort to move towards market economy while controlling land. They protested that "One cannot move towards a market economy while keeping land the most vital means of production on agricultural economy outside the operations of the market" (Samuel Gebre Selasie, 2006).

Very few writers try to search ways of minimizing the controversy by forwarding some options that narrow the polarized positions in between pro private and pro-state ownership debate. Deininger (2003) suggested that land use rights to be granted to land occupants or users in a formal long term lease. Allowing longer term leases (e.g. 30-99 years) encourages renters to engage in long term investment and development. According to him, if long term use rights are given the disparity between state ownership and private ownership could be narrowed and users could be more secure in their tenure. The experiences of other countries like China, Israel, and Vietnam are cited as examples that in these countries while land was owned by the state by means of long -term lease land tenure security and investment promoted. As cited in EEA (2002:40-49), when randomly selected farmers from different regions of the country asked "if you are given the right to use your current land as you wish, would you sell it partially or totally?" Over $90 \%$ of them were said to have responded "No we do not sell." Out of them some responded that in whatever conditions they will not sell their lands making EPRDF's up till now upheld 'fear' regarding land sale groundless.

Private ownership provides full rights to individual holders and allows them to participate more fully in the market economy (Belay Zerga, 2016). It secures land against intrusion by government, the primary threat to security of tenure in Africa. It permits free alienability which helps to move land in to the hands of more efficient producers (Tafesse O.2006). First, it provides opportunities for the landless to get access to land. Second, it server to provide a source of income for poor households. Third, it enables entrepreneurial peasants to expand 
their farm operations, and finally, it makes the land system to move from those who are unable to use it productively to those who can.

\subsection{Empirical evidences on polices and ideologies of land tenure}

The fear of the Ethiopian government with the privatization of the land could be that farmers may sell their land and face destitution. For instance, recent study made by Ethiopian Economic Association found that peasants were not keen to sell their land if they were given the chance (Desalegn, 2000). Dejene and Yigremew (2002) argued that the equity concerns of governments could be met through an appropriate policy instruments such as the specification of farm size without inhibiting land market. Desalegn Rahmato (2006) has criticized of the current Ethiopian Peoples' Revolutionary Democratic Front's (EPRDF) land policy as the policy promotes insecurity of tenure because it allows, among other things, periodic redistribution (or at least the threat of such redistribution); It is inefficient because it limits land transactions and has inhibited the emergence of a dynamic land market; It promotes fragmentation of land and growing pressure on land resources because it discourages rural people from leaving their farms for other employment opportunities.

According to Nega Berhanu (2003), the house holders' idea on the EPRDF police can be explained as follows. . The degree of support for the existing tenure arrangement, however, is not as strong as the government claims and varies significantly from region to region. In the predominantly pastoral areas of Somali (86 percent) and Afar (68 percent) as well as in the densely populated region of the South ( 78 percent), support is quite strong. There is strong opposition in the relatively sparsely populated Benishangul region where over 62 percent of the households oppose the current system. In the highland region of Tigray some two-thirds of the households are in favors of the current system whereas nearly 47 percent of the households in Amhara and 43 percent of the households in Oromiya do not like the current tenure arrangement; these do not represent a small minority.

The most important reason given for support of the existing tenure arrangement seems to be related to the user rights granted to farmers, as reported by 37 percent of those questioned, followed by 20 percent of the respondents who emphasized the equity/justice/ brought by the tenure system as a continuation of the 1975 land reform. Another 19.7 percent of the surveyed farmers feel that with the existing system they do not fear losing their plots (Nega, Berhanu 2003). Farmers opposing the prevailing land policy give their inability to obtain additional land as the dominant reason for their dissatisfaction (44 percent), followed by their inability to buy or sell land (13 percent), fear of losing land (12 percent) and injustice in land administration (11 percent).

The reasons provided are closely related to access to land, insecurity of tenure, absence of formal land markets and administrative injustice (Tesfaye T. \& Bedassa, T. 2002). Additional insecurity factors include expectations towards further land redistribution, i.e. how long farmers feel they can retain their current holding. Despite government claims that farmers feel they own the land they cultivate, the overwhelming majority of farmers ( 84 percent) know that as currently stipulated by laws and in practice, the land belongs to the government. Additionally, only 3.5 percent of the households believe that they can retain their current holding for over 20 years, and a significant majority (76 percent) does not feel secure that their claim towards their existing holding will last over 5 years. In terms of regional variation, except for Benishangul and the Southern region where the majority of respondents feel that they will retain their current holdings indefinitely, most respondents in Tigray, Amhara and Oromia are not sure how long they will be able to keep their current holding (B. Nega, et al., 2003).

The EPRDF considering itself as champion of the rural society strictly took state ownership of land as a guarantee for peasants and pastoralist tenure security; the rival political parties, on the other hand, argue that only giving the rural society full authority on their land as a private property will make them more secured and confident to improve and manage farm land (Yigremew,2001). The protagonists of the current debate are still busy either trying to persuade rivals to accept their rational or in making effort to bring the debate to an end in their own way.

On the other hand, each of them may not fully understand the adverse effect of deciding land policies without letting the concerned section of the society. Thus it will be better if contending parties listen what the people say and take into account the social, cultural and historical contexts of the society before designing and revising land policies and strategies ( Hoben A, 2002). However, the main stakeholder of the issue, the rural society, other than being told what has been decided, has not yet got involved in choosing what is better to it. Generally, the all approaches/options focused on holding back government's interference which cannot be practical elsewhere. And the contending parties are criticized for focusing on a single land tenure issue and for failing to listen to what the rural society pastoralists and peasants say about the issue under discussion. Therefore in some cases the rationale and assumptions of the contending groups discovered being invalid for each position fails to reflect the reality around the rural society. 


\section{CONCLUSIONS AND RECOMMENDATIONS}

\section{1 Conclusions}

The literature provides important insight into the outcome of land use certificates on tenure security of landholders in the different regions of Ethiopia. The review suppose that certification impact requires taking into account the socio-economic and cultural factors that define the use of land in rural Ethiopia, and to determine the effect of the certificates on land tenure insecurity of both male and female land holders. According to the review land certification has positive and significant impact on securing tenure of farm house holds. In addition most reviews explained that land registration will have a beneficial effect on land conservation. Other reported perceived advantages of land registration and certification include better tenure security, and the opportunity to lease land over a longer period of time. Conversely different authors show that some farm households do not want to register land, but were told to do so. Some fear less access to communal lands. While other said that it creates uncertainties and conflicts that enhance tenure insecurity for some groups and individuals. These results the review showed that land certificates have both positive and negative outcome on land conservation and investment. Regarding policy issue there is also a controversies idea both on policy makers and owner of lands. As explained above some agree with EPRDF ideologies, while other farm households disagree and wanted land to be free.

\subsection{Recommendations}

The government officials have been arguing for state ownership of land in the name of protecting the poor vulnerability form becoming landless "if land is under private and sold and bought'". On the other hand, private ownership of land is strongly recommended because it fosters security of tenure, environmental conservation. As explained in the review on the land policies, there are conflicting ideas not only in between political parities but also between farmers.

So it was needed greater compromise between political parities as well as between farmers.

- Although land certification has playing great role in securing the owner ship of farm house holds, according to the literature there is a gap between farm households in understanding of for what purpose the land titling should advised. Therefore, the issue ensuring tenure security among farmers needs additional awareness creation trainings.

- As cited by writers at kebele level the data of first level certification of land can be not set in an organized way and even it is susceptible to different damages. So it should computerize and attention should be given to securing tenure problem.

- Land certification in pastoralist's area need discussion with clans and Abba Gedas' since most of the land can be used as communal and they are not sedentary. Consequently in all situations concerned body should build consciousness of them.

- $\quad$ Regarding land policy debates all concerned bodies and parties should listen what the people say and take into account the social, cultural and historical contexts of the society before designing and revising land policies and strategies.

- The former EFDRE prime Minister as cited in Samuel (2006:78) defended that "land privatization in Ethiopia would take place only over the EPRDF's 'dead body'. This slogan should not participatory and it seems imposing political weapon over people and should be participatory of all stockholders including all rural land holders and all political parties.

\section{REFERANCES}

Abegaz, B., 2004. Escaping Ethiopia's poverty trap: the case for a second agrarian reform. The Journal of Modern African Studies, 42(3), pp.313-342.

Abera, T., Abera, D., Abera, Y., Gurmu, G. and Shimbir, T., Soil Fertility Management in Ethiopia: Research Findings, Challenges, Opportunities and Prospects. Agricultural Research for Ethiopian Renaissance.

Adal, Y., 2002. Review of landholding systems and policies in Ethiopia under the different regimes. Ethiopian Economic policy Research Institute working paper, Addis Ababa.

Ahene, R.A., 2009, March. Measures to improve access to land resources and related benefits in Uganda. In World Bank/FIG Conference on Land Governance in Support of the MDG's: Responding to New Challenges, Washington, DC.

Ali Daniel, A., Collin, M., Deininger, K., Dercon, S., Sandefur, J. and Zeitlin, A., 2011. Land titling in urban slums: The demand curve for property rights and the price of female empowerment. unpublished paper.

Ambaye, D.W., 2012, May. Land rights in Ethiopia: Ownership, equity, and liberty in land use rights. In FIG Working Week (p. 27).

Bekure, S., 2006. Benefits and costs of rural land titling: The international experience. Standardization of Rural Land Registration and Cadastral Surveying Methodologies. Experiences in Ethiopia. S. Bekure, G. Abegaz, L. Frej and S. Abebe. Addis Ababa, Ethiopia-Strengthening Land Tenure and Administration Program 
(ELTAP).

Bekure, S., 2006. Benefits and costs of rural land titling: The international experience. Standardization of Rural Land Registration and Cadastral Surveying Methodologies. Experiences in Ethiopia. S. Bekure, G. Abegaz, L. Frej and S. Abebe. Addis Ababa, Ethiopia-Strengthening Land Tenure and Administration Program (ELTAP).

Belay, A., 2010. The Effects of Rural Land Certification in Securing Land Rights: A Case of Amhara Region, Ethiopia. Unpublished thesis submitted to the international institute for geo-information science and earth observation, the Netherlands.

Bell, K.C., 2006, October. World Bank support for land administration and Management: responding to the Challenges of the Millennium Development Goals. In FIG Congress 2006 (pp. 8-13).

Benin, S. and Pender, J., 2001. Impacts of land redistribution on land management and productivity in the Ethiopian highlands. Land Degradation \& Development, 12(6), pp.555-568.

Benjaminsen, T.A., Holden, S., Lund, C. and Sjaastad, E., 2009. Formalisation of land rights: Some empirical evidence from Mali, Niger and South Africa. Land use policy, 26(1), pp.28-35.

Beyene, A., 2003. Soil conservation, land use and property rights in northern Ethiopia (Vol. 395).

Bezabih, M., Holden, S. and Mannberg, A., 2016. The role of land certification in reducing gaps in productivity between male-and female-owned farms in rural Ethiopia. The Journal of Development Studies, 52(3), pp.360-376.

Bezabih, M., Holden, S.T. and Mannberg, A., 2012. The role of land certification in reducing gender gaps in productivity in rural Ethiopia.

Brasselle, A.S., Gaspart, F. and Platteau, J.P., 2002. Land tenure security and investment incentives: puzzling evidence from Burkina Faso. Journal of Development Economics, 67(2), pp.373-418.

Bugri, J.T., 2008. The dynamics of tenure security, agricultural production and environmental degradation in Africa: Evidence from stakeholders in north-east Ghana. Land Use Policy, 25(2), pp.271-285.

Burns, T., Grant, C., Nettle, K., Brits, A.M. and Dalrymple, K., 2007. Land administration reform: indicators of success and future challenges. Agriculture and Rural Development Discussion Paper, 37, pp.1-227.

Clemens, M.A. and Kremer, M., 2016. The new role for the world bank. Journal of Economic Perspectives, 30(1), pp.53-76.

Cotula, L., Toulmin, C. and Hesse, C., 2004. Land tenure and administration in Africa: lessons of experience and emerging issues. London: International Institute for Environment and Development.

Crummey, D., 2006. Literacy in an oral society: The case of Ethiopian land records. Journal of African cultural studies, 18(1), pp.9-22.

Dani'el A., Mgumia, J. and Mvula, E. (2006).New challenges in land management and utilization in ruralTanzania;Bio-fuel cultivation in Rufijiand Mvomero districts http:// pubs.iied .org/pdfs/12560IIED.pdf] site visited on 12/03/2015.

De Soto, H., 2000. The mystery of capital: Why capitalism triumphs in the West and fails everywhere else. Basic Civitas Books.

Deininger, K. and Byerlee, D., 2011. Rising global interest in farmland: can it yield sustainable and equitable benefits?. The World Bank.

Deininger, K. and Feder, G., 2009. Land registration, governance, and development: Evidence and implications for policy. The World Bank Research Observer, 24(2), pp.233-266.

Deininger, K. and Jin, S., 2006. Tenure security and land-related investment: Evidence from Ethiopia. European Economic Review, 50(5), pp.1245-1277.

Deininger, K. and Jin, S., 2006. Tenure security and land-related investment: Evidence from Ethiopia. European Economic Review, 50(5), pp.1245-1277.

Deininger, K. and Jin, S., 2008. Land sales and rental markets in transition: Evidence from rural Vietnam. Oxford bulletin of Economics and Statistics, 70(1), pp.67-101.

Deininger, K., Ali, D.A. and Alemu, T., 2011. Impacts of land certification on tenure security, investment, and land market participation: evidence from Ethiopia. Land Economics, 87(2), pp.312-334.

Deininger, K., Ali, D.A., Holden, S. and Zevenbergen, J., 2008. Rural land certification in Ethiopia: Process, initial impact, and implications for other African countries. World Development, 36(10), pp.1786-1812.

Deininger, K., Jin, S., Adenew, B., Gebre-Selassie, S. and Demeke, M., 2003. Market and nonmarket transfers of land in Ethiopia: Implications for efficiency, equity, and nonfarm development. The World Bank.

Deininger, K., Zevenbergen, J. and Ali, D.A., 2006, May. Assessing the Certification Process of Ethiopia's Rural Lands. In Colloque International, At the Frontier of Land Issues: Social Embeddedness of Rights and Public Policy, Montpellier, France.

Deiningera, K., Zevenbergenb, J., Alic, D.A. and Zevenbergen, J., 2006. Assessing the Certification Process of Ethiopia's rural Lands Etablissement de la procédure de certification de terres rurales en Éthiopie. In Proceedings of the colloque international: Les frontières de la question foncière: at the frontier of land 
issues, Montpellier, 17-19 Mai, 2006. 14 p.

Delville, P.L., 2010. La reforme fonciere rurale au Benin. Revue française de science politique, 60(3), pp.467491.

Durand-Lasserve, A., Fernandes, E., Payne, G. and Rakodi, C., 2007, March. Social and economic impacts of land titling programmes in urban and peri-urban areas: a review of the literature. In World Bank Urban Research Symposium, Washington DC, May.

Evans, J. ed., 2009. Planted forests: uses, impacts and sustainability. Cabi.

Field, E., 2007. Entitled to work: Urban property rights and labor supply in Peru. The Quarterly Journal of Economics, 122(4), pp.1561-1602.

Gebremedhin, B., Pender, J. and Ehui, S., 2003. Land tenure and land management in the highlands of Northern Ethiopia.

Gebre-Selassie, A. and Bekele, T., 2010. A review of Ethiopian agriculture: roles, policy and small-scale farming systems. Ethiopia and DR Congo.

Gebre-Selassie, A. and Bekele, T., 2010. A review of Ethiopian agriculture: roles, policy and small-scale farming systems. Ethiopia and DR Congo.

Gebreselassie, S., 2006, March. Intensification of smallholder agriculture in Ethiopia: options and scenarios. In Future Agricultures Consortium Meeting at the Institute of Development Studies (pp. 20-22).

Gebreselassie, S., 2006, March. Intensification of smallholder agriculture in Ethiopia: options and scenarios. In Future Agricultures Consortium Meeting at the Institute of Development Studies (pp. 20-22).

Getahun, B.T., 2015. Historiographical review of the current debate on Ethiopian land tenure system. African Journal of History and culture, 7(2), pp.044-051.

Getahun, B.T., 2015. Historiographical review of the current debate on Ethiopian land tenure system. African Journal of History and culture, 7(2), pp.044-051.

Getahun, B.T., 2015. Historiographical review of the current debate on Ethiopian land tenure system. African Journal of History and culture, 7(2), pp.044-051.

Ghebru, H. and Holden, S.T., 2015. Technical efficiency and productivity differential effects of land right certification: A quasi-experimental evidence. Quarterly Journal of International Agriculture, 54(1), pp.1-31.

Giri, S., 2010. The effect of rural land registration and certification programme on farmers' investments in soil conservation and land management in the Central Rift Valley of Ethiopia.

Hagos, H.G. and Holden, S.T., 2015. Technical Efficiency and Productivity Differential Effects of Land Right Certification: A Quasi-Experimental Evidence.

Haile, M., Witten, W., Abraha, K., Fissha, S., Kebede, A., Kassa, G. and Reda, G., 2005. Research Report 2 Land Registration in Tigray, Northern Ethiopia. IIED, Mekelle University and Central Research Department, DFID.

Hailu, Z., 2016. Land Governance Assessment Framework Implementation in Ethiopia.

Holden, S. and Yohannes, H., 2002. Land redistribution, tenure insecurity, and intensity of production: A study of farm households in Southern Ethiopia. Land Economics, 78(4), pp.573-590.

Holden, S.T. and Bezabih, M., 2008. Gender and land productivity on rented land in Ethiopia. The emergence of land markets in Africa: Assessing the impacts on poverty, equity and efficiency, pp.179-98.

Holden, S.T., Deininger, K. and Ghebru, H., 2009. Impacts of low-cost land certification on investment and productivity. American Journal of Agricultural Economics, 91(2), pp.359-373.

Holden, S. and Tefera, T., 2008. From being property of men to becoming equal owners? Early impacts of land registration and certification on women in southern Ethiopia. Unpublished report for UNHABITAT

Hosaena Ghebru, H. and Holden, S.T., 2013. Reverse-Share-Tenancy and Marshallian Inefficiency: Landowners' Bargaining Power and Sharecroppers' Productivity.

Hosaena Ghebru, H. and Holden, S.T., 2013. Links between Tenure Security and Food Security: Evidence from Ethiopia.

Hundie, B., 2006, June. Property rights among Afar pastoralists of northeastern Ethiopia: forms, changes and conflicts. In Survival of the Commons: Mounting Challenges and New Realities. Eleventh Conference of the International Association for the Study of Common Property, Bali, Indonesia.

Jacoby, H.G. and Minten, B., 2007. Is land titling in Sub-Saharan Africa cost-effective? Evidence from Madagascar. The World Bank Economic Review, 21(3), pp.461-485.

Kabubo-Mariara, J. and Linderhof, V., Tenure Security, Sustainable Land Management and Poverty: Case Studies from Kenya. Internet file retrieved from home. tiscali. nl/linderhof/KabuboMariara_Linderhoftenure\% 20security\% 20and\% 20SLM. pdf on, 7.

Kuusaana, E.D., Kidido, J.K. and Halidu-Adam, E., 2013. Customary land ownership and gender disparityevidence from the wa municipality of Ghana. Ghana Journal of Development Studies, 10(1-2), pp.63-80.

Lamba, A., 2005. Land tenure management systems in informal settlements. Unpublished MSc Thesis, University of Twente Faculty of Geo-Information and Earth Observation (ITC). 
Lavigne Delville, P., 2010. Tenure security, formalization of rights, land regulation institutions and investments. For a broader conceptual framework. Land Tenure Journal, 1(1).

Liu, M. and Yin, Y., 2010. Human Development in East and Southeast Asian Economies: 1990-2010. Human Development, p.17.

Lugoe, F., 2008. Assessment of main urban land use issues in Tanzania. Report Prepared for World Bank Urban Team AFTU1 on Tanzania Local Government Support Project. Online, available under http://www. dilaps. or. tz/Downloads. html, retrieved, 3, p.2011.

Lyons, K., 2001. Undertaking land administration projects: sustainability, affordability, operational efficiency and good practice guidelines (No. 26). AusAID.

McKee, A.C., Cairns, N.J., Dickson, D.W., Folkerth, R.D., Keene, C.D., Litvan, I., Perl, D.P., Stein, T.D., Vonsattel, J.P., Stewart, W. and Tripodis, Y., 2016. The first NINDS/NIBIB consensus meeting to define neuropathological criteria for the diagnosis of chronic traumatic encephalopathy. Acta neuropathologica, 131(1), pp.75-86

Michael, Y.G., Hadgu, K. and Ambaye, Z., 2005. Addressing pastoralist conflict in Ethiopia: the case of the Kuraz and Hamer sub-districts of South Omo zone.

Milkias, P., 2006. The role of civil society in promoting democracy and human rights in Ethiopia. Mariano polis College/Concordia University.

Mitiku, H., Herweg, K.G. and Stillhardt, B., 2006. Sustainable land management: A new approach to soil and water conservation in Ethiopia

Nakaya, H., 2010. The Implementation of Cambodia's Laws on Land Tenure (Doctoral dissertation, Nagoya University).

Nega, B., Adenew, B. and Gebre Sellasie, S., 2003. Current land policy issues in Ethiopia. Land Reform, Land Settlement, and Cooperatives, 11(3), pp.103-24.

Palm, L., 2010. Quick and cheap mass land registration and computerisation in Ethiopia. Facing the ChallengesBuilding the Capacity.

Peters, P.E. and Kambewa, D., 2007. Whose security? Deepening social conflict over 'customary'land in the shadow of land tenure reform in Malawi. The Journal of Modern African Studies, 45(3), pp.447-472.

Rahmato, D. and Assefa, T. eds., 2006. Land and the challenge of sustainable development in Ethiopia: Conference Proceedings. African Books Collective.

Rahmato, D., 2004. Searching for tenure security?: the land system and new policy initiatives in Ethiopia. Forum for Social Studies.

Sanga, R.T., 2009, March. Assessing the impact of customary land rights registration on credit access by farmers in Tanzania: A case study in Mbozi district. ITC.

Sikor, T., 2006. Politics of rural land registration in post-socialist societies: Contested titling in villages of Northwest Vietnam. Land Use Policy, 23(4), pp.617-628.

Steudler, D., A. Rajabifard, (2004). "Evaluation of land administration systems." Land Use Ethiopian Journal for development research. 17 (1):25-39.

STUDIES, L.T., 2003. The design of land consolidation pilot projects in Central and Eastern Europe. FAO Land Tenure Studies, 6.

TAGOE, N.D., MANTEY, S., ADJEI, S. and Soakodan, M., The Role of the Land Surveyor in Land Acquisition and Compensation-A Case Study of the Tarkwa Mining Communities, Ghana.

Teklu, Tesfaye. "Rural land, emerging rental land markets and public policy in Ethiopia." African Development Review 16, no. 1 (2004): 169-202.

Temesgen Gebeyehu, (2013).Peasants, land reform and property right in Ethiopia: The experience of Gojjam Province, 1974 to 1997.

Tommasoli, M., 1996. Traditional institutions, social change and development in post-conflict Ethiopia. Africa: Rivista trimestrale di studi e documentazione dell'Istituto italiano per l'Africa e l'Oriente, 51(4), pp.563586.

Toulmin, C. and Quan, J., 2000. Evolving land rights, policy and tenure in Africa. DFID/IIED/NRI.

Toulmin, C., 2009. Securing land and property rights in sub-Saharan Africa: the role of local institutions. Land use policy, 26(1), pp.10-19.

Tuladhar, A., 2004. Parcel-based geo-information system: concepts and guidelines. ITC.United Nations. Economic Commission for Africa, 2004. Land tenure systems and their impacts on food security and sustainable development in Africa. Economic Commission for Africa.

Van der Molen, P., 2002. The dynamic aspect of land administration: an often-forgotten component in system design. Computers, Environment and Urban Systems, 26(5), pp.361-381

Wily, L.A., 2008. Custom and commonage in Africa rethinking the orthodoxies. Land use policy, 25(1), pp.4352.

Wubneh, M., 2018. Policies and praxis of land acquisition, use, and development in Ethiopia. Land use 
policy, 73, pp.170-183.

Zerga, B., 2016. Land Resource, Uses, and Ownership in Ethiopia: Past, Present and Future.

Zevenbergen, J., 2005. Implementing new land legislation in Africa. Tenure security and certification in rural Ethiopia. 